\title{
PENERAPAN PARTICLE SWARM OPTIMIZATION (PSO) UNTUK KLASIFIKASI DAN ANALISIS KREDIT DENGAN MENGGUNAKAN ALGORITMA C4.5
}

\author{
Saprudin \\ Teknik Informatika Universitas Pamulang \\ Jl. Surya Kencana No. 1, Pamulang, Tangerang Selatan-Indonesia \\ E-mail : dosen00836@unpam.ac.id
}

\begin{abstract}
ABSTRAK
Teknik klasifikasi saat ini sudah banyak digunakan untuk mengatasi permasalahan yang terkait dengan penggolongan data. Implementasi teknik klasifikasi ini dapat diterapkan pada berbagai bidang. Tujuan utama dari metode klasifikasi adalah proses penemuan model (fungsi) yang menggambarkan dan membedakan kelas data. Salah satu metode yang paling baik untuk klasifikasi adalah algoritma C4.5. Untuk itu penulis menggunakan metode klasifikasi C4.5, dan untuk dapat meningkatkan nilai akurasinya dioptimasi dengan PSO (Particle Swarm Optimization) dimana data uji yang digunakan adalah Data German Credit. Dari hasil percobaan yang dilakukan model algoritma C4.5 berbasis Particle Swarm Optimization (PSO) mendapatkan hasil terbaik yaitu 70\%, sedangkan model algoritma C4.5 tanpa Particle Swarm Optimization ( PSO) hanya 68,6\%, sehingga selisih untuk nilai akurasi sebesar 1,4\%. Dapat disimpulkan bahwa penerapan teknik optimasi particle swarm optimization dapat meningkatkan nilai akurasi pada algoritma C4.5.
\end{abstract}

Kata kunci: Klasifikasi, Optimasi, Algoritma C4.5

\section{PENDAHULUAN}

Analisis kredit adalah sistem atau cara yang digunakan oleh Bank atau lembaga pembiayaan lainnya untuk menentukan kelayakan calon debitur untuk mendapatkan pinjaman. Penelitian ini menggunakan German Credit Dataset yang diperoleh dari UCI Machine Learning Repository, data tersebut merupakan data debitur yang telah melakukan kredit pada Bank Jerman yang terdiri dari 1000 record dengan 20 variabel.

Algoritma klasifikasi akan menggunakan data latihan untuk menghasilkan pengetahuan agar dapat menggolongkan resiko kredit seorang nasabah pada masa mendatang berdasarkan variabel-variabel yang ada.

Analisa dengan metode klasifikasi sendiri adalah proses penemuan model (fungsi) yang menggambarkan dan membedakan kelas data atau konsep yang bertujuan agar bisa digunakan untuk memprediksi kelas dari objek yang label kelasnya tidak diketahui (Han, 2006).

Menurut Gartner Group data mining adalah suatu proses menemukan hubungan yang berarti, pola, dan kecenderungan dengan memeriksa dalam sekumpulan besar data yang tersimpan dalam penyimpanan dengan menggunakan teknik pengenalan pola seperti teknik statistik dan matematika (Larose, 2006).

\section{METODE PENELITIAN}

\subsection{Analisa dan Desain Penelitian}

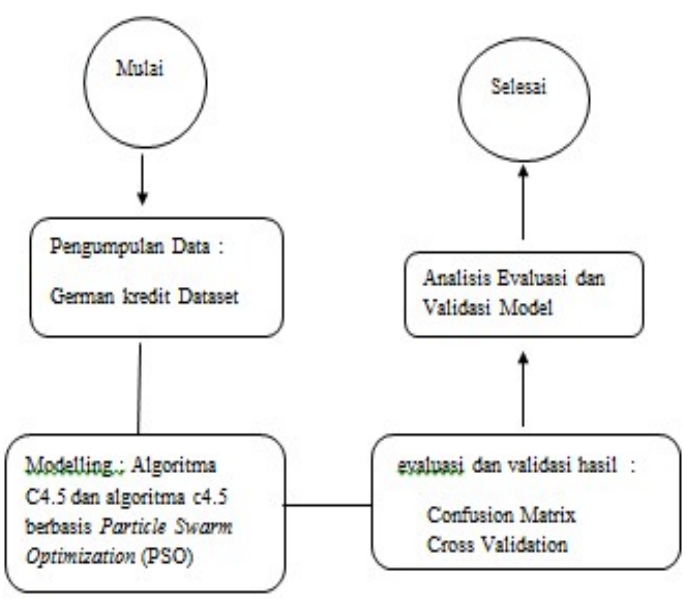

Gambar 2.1 Alur Analisis Penelitian

\subsection{Bussiness understanding}

Banyaknya kasus nasabah kredit macet yang terjadi dapat membuat masalah dan berdampak pada ruginya suatu bank, oleh karena itu di butuhkan analisa yang tepat sebagai solusinya. Algoritma c4.5 adalah salah satu metode klasifikasi yang sering di gunakan untuk menganalisa kredit dengan tujuan agar analisa lebih akurat, ditambah lagi dengan pengembangan yang dilakukan dengan menambahkan Particle 
Swarm Optimization (PSO) di harap dapat lebih membantu dalam menganalisa di bandingkan hanya menggunakan algoritma c4.5 saja.

\subsection{Data Understanding}

Penelitian ini nantinya akan menggunakan data uji yang banyak dipakai dalam permasalahan klasifikasi untuk penilaian kelayakan pemberian kredit yang disebut German Credit Dataset, data set ini didonasikan oleh Prof. Hofman dari Hamburg University, Jerman. Dataset ini terdiri dari 1000 record dan 20 variabel ditambah dengan sebuah variabel target atau variabel response, dimana 13 variabel diantaranya bertipe kategori dan sisanya sebanyak 7 variabel bertipe numerik. German Credit Dataset ini dapat diunduh di UCI Machine Learning Repository.

\subsection{Data Preparation}

(Sugiyono, 2002) mengemukakan bahwa populasi adalah wilayah yang terdiri atas obyek atau subyek yang mempunyi kualitas dan karakteristik tertentu yang ditetapkan oleh peneliti untuk dipelajari dan kemudian ditarik kesimpulannya.

Pada tahapan ini di pakai data sebanyak 1000 record dan 20 variabel ditambah dengan sebuah variabel target atau variabel response, sebelumnya akan dilakukan beberapa penyeleksian untuk menghasilkan data yang dibutuhkan, antara lain:

1. Data Cleaning untuk membersihkan nilai yang kosong atau tupel yang kosong..

2. Data Integration yang berfungsi menyatukan tempat peyimpanan yang berbeda kedalam satu data. Dalam kasus ini hanya ada satu tempat penyimpanan data yaitu status di terima atau tidaknya kredit nasabah.

3. Data reduction jumlah atribut yang digunakan

\section{HASIL DAN PEMBAHASAN}

\subsection{Pengukuran Penelitian}

\subsubsection{Hasil Penelitian}

Mengembangkan model yang sudah terbentuk dengan algoritma klasifikasi C4.5.serta melakukan perbandingan menggunakan Algoritma Klasifikasi C4.5 dan Algoritma Klasifikasi C4.5 berbasis Particle Swarm Optimization.

\subsubsection{Evaluasi dan Validasi Model}

1. Hasil Perhitungan Entropy dan Gain
Contoh perhitungan sederhana memakai tiga atribut :

Tabel 3.1perhitungan node dengan tiga atribut

\begin{tabular}{|c|c|c|c|c|c|c|c|c|}
\hline No & & & & $\begin{array}{l}\text { JUMLAH } \\
\text { KASUS }\end{array}$ & YES & No & ENTROPY & GAIN \\
\hline \multirow[t]{24}{*}{1} & TOTAL & & & 1000 & 700 & 300 & 0.881290899 & \\
\hline & & $\begin{array}{l}\text { Status } \\
\text { of } \\
\text { existing } \\
\text { checking } \\
\text { account }\end{array}$ & & & & & & 0.095463104 \\
\hline & & & A11 & 274 & 139 & 135 & 0.999846263 & \\
\hline & & & A 12 & 268 & 163 & 105 & 0.965945651 & \\
\hline & & & A 13 & 62 & 48 & 14 & 0.770629069 & \\
\hline & & & A 14 & 396 & 350 & 46 & 0.518225966 & \\
\hline & & $\begin{array}{l}\text { Credit } \\
\text { history }\end{array}$ & & & & & & 0.043617799 \\
\hline & & & A 30 & 40 & 15 & 25 & 0.954434003 & \\
\hline & & & A 31 & 49 & 21 & 28 & 0.985228136 & \\
\hline & & & A 32 & 530 & 361 & 169 & 0.903146117 & \\
\hline & & & A 33 & 88 & 60 & 28 & 0.902393283 & \\
\hline & & & A 34 & 293 & 243 & 50 & 0.659186043 & \\
\hline & & Purpose & & & & & & 0.023058443 \\
\hline & & & A 40 & 233 & 145 & 88 & 0.956388718 & \\
\hline & & & A41 & 102 & 85 & 17 & \begin{tabular}{|l}
0.650022422 \\
\end{tabular} & \\
\hline & & & A 42 & 181 & 123 & 58 & 0.904861457 & \\
\hline & & & A 43 & 280 & 218 & 62 & 0.762767467 & \\
\hline & & & A 44 & 0 & 0 & 0 & 0 & \\
\hline & & & A 45 & 22 & 14 & 8 & 0.945660305 & \\
\hline & & & A 46 & 50 & 28 & 22 & 0.989587521 & \\
\hline & & & A 47 & 0 & 0 & 0 & 0 & \\
\hline & & & A 48 & 23 & 17 & 6 & 0.828055725 & \\
\hline & & & A 49 & 97 & 63 & 34 & 0.934527566 & \\
\hline & & & A410 & 12 & 7 & 5 & 0.979868757 & \\
\hline
\end{tabular}

Dari tabel 3.1 di atas dapat diketahui bahwa atribut dengan gain tertinggi adalah Status of existing checking account yaitu sebesar 0,095463104. Dengan demikian Status of existing checking account dapat njadi akar.berikut keterangan dengan gambar pohon keputusannya.

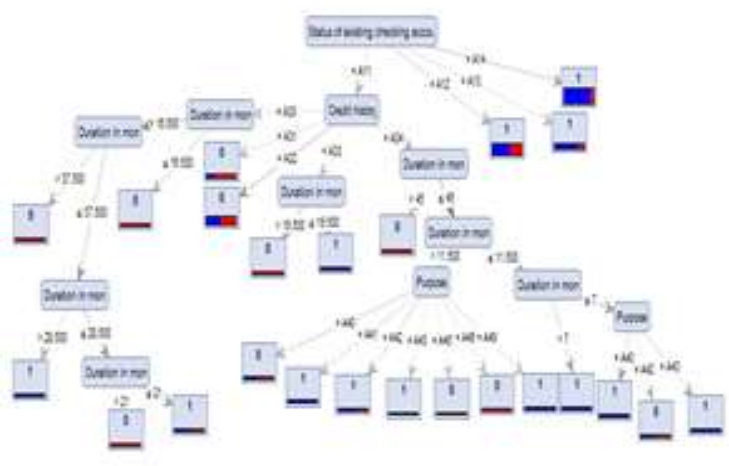

Gambar 3.1 pohon keputusan tiga atribut

Rincian aturan pohon keputusan pada gambar 4.1 di atas adalah sebagai berikut :

1. $\mathrm{R} 1=I F$ Status of existing checking account A11, AND Credit Histori A30, AND Duration in month $>16.500$, AND Duration in month $>37.500$, THEN class $=N O$

2. $\mathrm{R} 2=I F$ Status of existing checking account A11, AND Credit Histori A30, AND Duration in month $>16.500$, AND Duration in 
month $<=37.500$, AND Duration in month $>28.500$ THEN class $=$ YES

3. $\mathrm{R} 3=$ IF Status of existing checking account A11, AND Credit Histori A30, AND Duration in month $>16.500$, AND Duration in month $<=37.500$, AND Duration in month $<=28.500$, AND Duration in month $>21$, THEN class $=N O$

4. $\mathrm{R} 4=$ IF Status of existing checking account A11, AND Credit Histori A30, AND Duration in month $>16.500$, AND Duration in month $<=37.500$, AND Duration in month $<=28.500$, AND Duration in month $<=21$, THEN class $=Y E S$

5. R5 = IF Status of existing checking account A11, AND Credit Histori A30, AND Duration in month $<=16.500$, THEN class $=$ NO

6. R6 = IF Status of existing checking account A11, AND Credit Histori A31, THEN class $=N O$

7. R67=IF Status of existing checking account A11, AND Credit Histori A32, THEN class $=N O$

8. $\mathrm{R} 8=$ IF Status of existing checking account A11, AND Credit Histori A33, AND Duration in month $>19.500$, THEN class $=$ $\mathrm{NO}$

9. $\mathrm{R} 9=$ IF Status of existing checking account A11, AND Credit Histori A33, AND Duration in month $<=19.500$, THEN class $=$ YES

10. R10 = IF Status of existing checking account A11, AND Credit Histori A34, AND Duration in month $>45$, THEN class $=N O$

11. R11 = IF Status of existing checking account A11, AND Credit Histori A34, AND Duration in month $>45$, AND Duration in month $>11.500$, AND purpose A40, THEN class $=N O$

12. $\mathrm{R} 12$ = IF Status of existing checking account A11, AND Credit Histori A34, AND Duration in month $>45$, AND Duration in month $>11.500$, AND purpose A41, THEN class $=$ YES

13. R13 = IF Status of existing checking account A11, AND Credit Histori A34, AND Duration in month $>45$, AND Duration in month $>11.500$, AND purpose A42, THEN class $=$ YES

14. R11 = IF Status of existing checking account A11, AND Credit Histori A34, AND Duration in month $>45$, AND Duration in month $>11.500$, AND purpose A43, THEN class $=$ YES

15. R15 = IF Status of existing checking account A11, AND Credit Histori A34, AND Duration in month $>45$, AND Duration in month $>11.500$, AND purpose A44, THEN class $=N O$

16. R16 = IF Status of existing checking account A11, AND Credit Histori A34, AND Duration in month $>45$, AND Duration in month $>11.500$, AND purpose A46, THEN class $=N O$

17. $\mathrm{R} 17=I F$ Status of existing checking account A11, AND Credit Histori A34, AND Duration in month $>45$, AND Duration in month $>11.500$, AND purpose A49, THEN class $=$ YES

18. R18 = IF Status of existing checking account A11, AND Credit Histori A34, AND Duration in month $<=45$, AND Duration in month $<=11.500$, AND Duration in month $>7$, THEN class $=$ YES

19. R19= IF Status of existing checking account A11, AND Credit Histori A34, AND Duration in month $<=45$, AND Duration in month $<=11.500$ AND Duration in month $<=7$, AND purpose A40, THEN class $=$ $Y E S$

20. $\mathrm{R} 20=$ IF Status of existing checking account A11, AND Credit Histori A34, AND Duration in month $<=45$, AND Duration in month $<=11.500$ AND Duration in month $<=7$, AND purpose A42, THEN class $=N O$

21. R21= IF Status of existing checking account A11, AND Credit Histori A34, AND Duration in month $<=45$, AND Duration in month $<=11.500$ AND Duration in month $<=7$, AND purpose A43, THEN class $=$ $Y E S$

22. R22= IF Status of existing checking account A12, THEN class $=$ YES

23. R23= IF Status of existing checking account A13, THEN class = YESR24=IF Status of existing checking account A14, THEN class $=Y E S$

Tabel 3.2 Perhitungan Node Sepenuhnya 


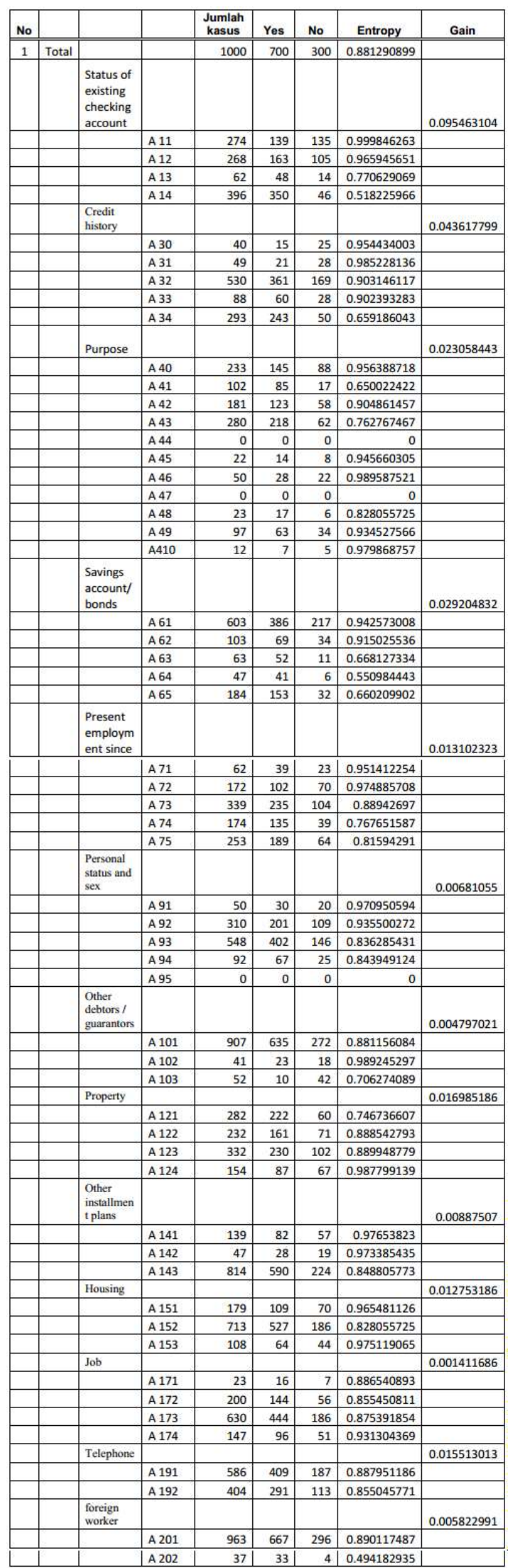

Pohon keputusan algoritma c4.5 berbasis Particle Swarm Optimization (PSO) dengan minimal gain 0.1

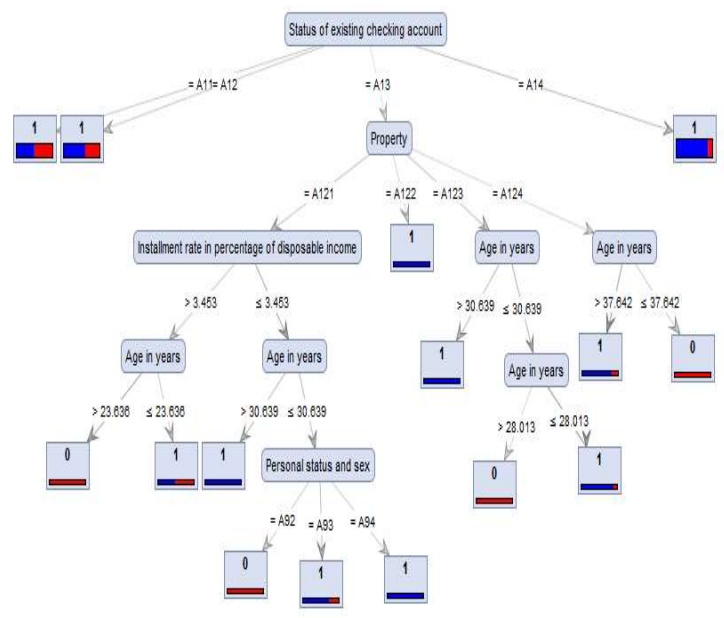

Gambar 4.2 pohon keputusan algoritma c4.5 berbasis Particle Swarm Optimization(PSO)

Rincian aturan pohon keputusan pada gambar 4.3 di atas adalah sebagai berikut :

1. $\mathrm{R} 1=I F$ Status of existing checking account A11, THEN CLASS = YES

2. $\mathrm{R} 2=$ IF Status of existing checking account A12, THEN CLASS = YES

3. R3 = IF Status of existing checking account A13, AND property A121, AND Installment rate in percentage of disposable income $>$ 3.453, AND age in years >23.636, THEN $C L A S S=N O$

4. R4 = IF Status of existing checking account A13, AND property A121, AND Installment rate in percentage of disposable income $>$ $3.453, A N D$ age in years $<=23.636$, THEN $C L A S S=Y E S$

5. R5 = IF Status of existing checking account $\mathrm{A} 13$, AND property A121, AND Installment rate in percentage of disposable income $>$ 3.453, AND age in years $>30.639$, THEN $C L A S S=N O$

6. R6 = IF Status of existing checking account A13, AND property A121, AND Installment rate in percentage of disposable income $>$ $3.453, A N D$ age in years $<=30.639, A N D$ personal status and sex A 92, THEN CLASS $=N O$

7. $\mathrm{R} 7=I F$ Status of existing checking account A13, AND property A121, AND Installment rate in percentage of disposable income $>$ 3.453 , AND age in years $<=30.639, A N D$ personal status and sex A 93, THEN CLASS $=Y E S$ 
8. $\mathrm{R} 8=I F$ Status of existing checking account A13, AND property A121, AND Installment rate in percentage of disposable income $>$ 3.453, $A N D$ age in years $<=30.639, A N D$ personal status and sex A 94, THEN CLASS $=Y E S$

9. $\mathrm{R} 9=$ IF Status of existing checking account A113, AND property A122, THEN CLASS = YES

10. $\mathrm{R} 10=I F$ Status of existing checking account A13, AND property A123, AND age in years $>30.639$, THEN CLASS $=$ YES

11. R11=IF Status of existing checking account A13, AND property A123, AND age in years $<=30.639$, AND age in years $>28.013$ THEN $C L A S S=N O$

12. $\mathrm{R} 12=I F$ Status of existing checking account $\mathrm{A} 13$, AND property A123, AND age in years $<=30.639$, AND age in years $<=28.013$ THEN CLASS = YES

13. $\mathrm{R} 13=$ IF Status of existing checking account A13, AND property A124, AND age in years >37.642, THEN CLASS $=$ YES

14. R14 = IF Status of existing checking account $\mathrm{A} 13$, AND property A124, AND age in years $<=37.642$, THEN CLASS $=N O$

15. R15 = IF Status of existing checking account A14, THEN CLASS $=$ YES

\section{Hasil Pengujian}

a. Evaluasi model dengan Confusion Matrix

Tabel 3.4 Konversi confusion matrix algoritma klasifikasi C4.5 berbasis PSO

\begin{tabular}{llll}
\hline \multicolumn{2}{|c|}{ accuracy:70.00\%+1.0.00\% (mikro:70.00\%) } & & \\
\hline \hline & true 1 & tue 0 & dass precision \\
\hline pred. 1 & 700 & 300 & $70.00 \%$ \\
\hline pred. 0 & 0 & 0 & $0.00 \%$ \\
\hline class recall & $100.00 \%$ & $0.00 \%$ & \\
\hline
\end{tabular}

Pada Confusion Matrix di atas, Actual/ sebenarnya ada 1000 predikat 1 (positive), namun system memprediksi ada 700 predikat 1 (positive) , 300 predikat 0 (negative), 0 predikat 0 (positif), dan 0 predikat 0 (negative).

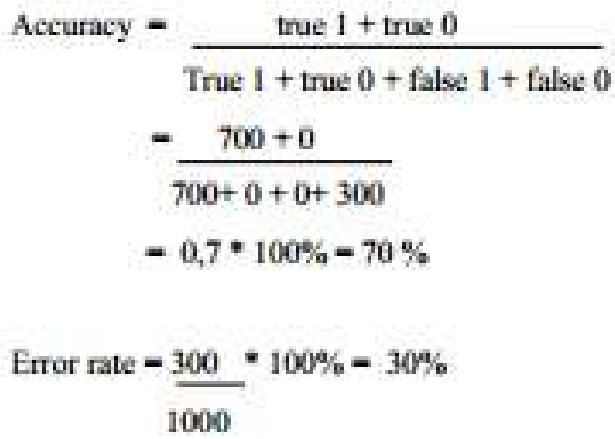

Berdasarkan Tabel 3.4 menunjukan bahwa, tingkat akurasi menggunakan algoritma klasifikasi C4.5 berbasis PSO adalah sebesar 70\% dan error ratenya sebesar $30 \%$.

\subsection{Analisis Evaluasi dan Validasi Model}

Dari hasil pengujian diatas, dengan dilakukannya evaluasi secara confusion matrix ternyata terbukti bahwa pengujian yang dilakukan dengan menggunakan algoritma klasifikasi C4.5 berbasis PSO memiliki nilai akurasi yang lebih tinggi dibanding hanya menggunakan algoritma klasifikasi C4.5.

Nilai akurasi untuk model algoritma klasifikasi C4.5 sebesar 68,6\% dan nilai akurasi algoritma klasifikasi $\mathrm{C} 4.5$ berbasis PSO (Particle Swarm Optimization) sebesar $70 \%$ dengan selisih akurasi sebesar 1,4\%, dapat dilihat pada Tabel 3.3 dibawah ini.

Tabel 3.3 Pengujian Algoritma klasifikasi C4.5 dan C4.5 berbasis PSO

\begin{tabular}{lc}
\hline & Accuracy \\
\hline C4.5 & $68,6 \%$ \\
\hline C4.5 berbasis PSO & $70 \%$ \\
\hline
\end{tabular}

\section{KESIMPULAN}

Hasil penelitian untuk nilai akurasi algoritma klasifikasi C4.5 senilai $68,6 \%$ sedangkan untuk nilai akurasi algoritma klasifikasi C4.5 berbasis PSO senilai $70 \%$ sehingga selisih untuk nilai akurasi sebesar 1,4 $\%$. Sehingga dapat disimpulkan bahwa penerapan teknik optimasi particle swarm optimization dapat meningkatkan nilai akurasi pada algoritma $\mathrm{C} 4.5$ 


\section{SARAN}

Berdasarkan proses pengujian dan kesimpulan yang telah dilakukan, maka ada beberapa saran dalam penelitian ini adalah:

1. Menambahkan jumlah data dan atribut lebih banyak lagi, sehingga bisa menentukan keakuratan suatu metode dengan lebih baik lagi.

2. Menggunakan metode prediksi dan optimasi lain sehingga dapat memperkaya pengetahuan khususnya di bidang metode datamining.

3. Menggunakan program software rapiminer yang lebih terbaru.

4. Meningkatkan lagi sistem analisa kredit untuk penentuan kelayakan pemberian kredit

\section{DAFTAR PUSTAKA}

[1] Sugiyono. (2002). Metode Penelitian Bisnis. Bandung: CV. Alfabeta.

[2] Olson, David dan Yong Shi (2007) Introduction to Business Data Mining, Boston:McGraw-Hill.

[3] Sulianta, Feri dan Dominikus Juju (2010) Data Mining Meramalkan Bisnis

Perusahaan, Jakarta: Elex Media Komputindo.

[4] Hair, Joseph, et al (1995.) Multivariate Data Analysis with Readings,Englewood

Cliffs: Prentice

[5] Hall.Han, J., \& Kamber, M. (2006). Data Mining Concepts and Techniques. San Francisco: Diane Cerra.

[6] Larose, D. T. (2005). Discovering Knowledge In Data. Canada: WileyInterscience.

[7] Fayyad, Usama. (1996) Advances in Knowledge Discovery and Data Mining. MIT

Press.

[8] X. Hu, R. Eberhart, and Y. Shi. Particle swarm with extended memory for multiobjective optimization, IEEE Swarm Intelligence Symposium 2003, Indianapolis, IN, USA

[9] X. Hu, R. Eberhart, and Y. Shi. Recent advances in particle swarm, , IEEE Congress on Evolutionary Computation 2004, Portland, Oregon, USA

[10]Gorunescu, F. (2011). Data Mining Concepts, Model and Techniques. Berlin: Springer. 